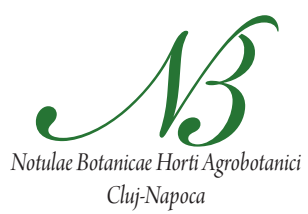

\title{
Effects of Different Deficit Irrigation Strategies on Yield, Fruit Quality and Some Parameters: 'Braeburn' Apple Cultivar
}

\author{
Cenk KÜÇÜKYUMUK*, Emel KAÇAL, Halit YILDIZ \\ Fruit Research Station, 32500, Eğirdir, Isparta, Turkey; cenkkucukyumuk@hotmail.com \\ ('correspondingauthor); emelvural101@hotmail.com; halityildiz@hotmail.com
}

\begin{abstract}
This study was conducted to determine the effects of deficit irrigation applied in different periods to dwarf rootstock apple trees (cv. 'Braeburn')on vegetative development, yield, fruit quality and marketable yield for three years (2010-2012). There were six different treatments (none deficit irrigation, $\mathrm{T}_{1}$; continuous deficit irrigation, $\mathrm{T}_{2}$; deficit irrigation between the $40^{\text {th }}$ and $70^{\text {th }}$ days after full bloom, $\mathrm{DAFB}, \mathrm{T}_{3}$; deficit irrigation between the $70^{\text {th }}$ and $100^{\text {th }} \mathrm{DAFB}, \mathrm{T}_{4}$; deficit irrigation between the $100^{\text {th }}$ and $130^{\text {th }} \mathrm{DAFB}, \mathrm{T}_{5}$; deficit irrigation between the $130^{\text {th }}$ and $160^{\text {th }} \mathrm{DAFB}, \mathrm{T}_{6}$ ). It was determined that short-term (30 days) deficit irrigation treatments during growing season resulted in decrease for vegetative development and yield. The apples that have both the highest marketable yield and the highest red colour density were obtained from $\mathrm{T}_{3}$ in deficit irrigation treatments. $\mathrm{T}_{3}$ treatments saved irrigation water according to $\mathrm{T}_{1}$ treatment in study years (12.4\%, $14.4 \%$ and 15.2 respectively). For more efficient use of water resources in case of limited irrigation water, $\mathrm{T}_{3}$ treatment was found to be recommendable for apple growers because it not only saves water but also affects yield and fruit quality least.
\end{abstract}

Key words: M9 rootstock, marketable yield, vegetative development, water saving

\section{Introduction}

The major part (approximately 70\%) of water both in Turkey and in the world is used in agricultural production. However, as the ratio of water use increases due to rapidly increasing population and developing industry, water amounts used in agriculture decreases (Önder $e t$ al., 2005). For this reason, researches conducted on new irrigation techniques that not only save water but also negatively affect yield and fruit quality less (deficit irrigation, periodic deficit irrigation, partial root zone drying etc.) become more of an issue.

The primary objective of all irrigation studies is to maximize yield and fruit quality in fruit growing. It is possible to decrease competition between fruit growth and shoot growth and thus to increase fruit size and quality with right timing in irrigation (Dennis, 1996). In recent studies, it has been found that deficit irrigation applied to apple in different periods affects yield and fruit quality differently (Mpelasoka et al., 2001; O'Connell and Goodwin, 2007; Zaliha and Singh 2009a,b). In case of apple, there are numerous studies, which have been conducted on the effectiveness of deficit irrigation applications compared to none deficit irrigation applications. However, they usually cover a single year period; no long-term research results exist (Girona et al., 2010; Behboudian et al., 2011). Deficit irrigation strategies are recommended for saving irrigation water without a considerable reduction in yield for fruit trees (Chalmers et al., 1981). However, this approach needs complete and exact information about the responses of trees to water stress in different phenological stages so as to determine the periods when fruit trees are less sensitive to stress. It is necessary for fruit growing to determine and know the application period of deficit irrigation (Fereres and Goldhamer, 1990).

Apple is one of the most important fruits produced in Turkey. Apple production in Turkey is estimated as 3.1\% of the world production. Isparta is a very important apple growing region of Turkey with a production accounting for nearly 26\% of the country's total (Anonymous, 2012). This study aimed at determining the deficit irrigation period, which saves most irrigation water and has the least negative effects on yield and marketable yield. In addition, it intended to increase red colour density as an important criterion in marketing for 'Braeburn' apple cultivar.

\section{Materials and methods}

\section{Study area and plant material}

This study was conducted at Fruit Research Station (3749'18.24”'N, 30'52'22.90”'E, Eğirdir, Isparta-Turkey) for 3 years (2010 and 2012). Apple trees were planted in 2000 (3.5 m x $1.5 \mathrm{~m}$ spacing) and 'Braeburn' apple cultivar grafted on M9 rootstock was used in this study. Some physical and chemical characteristics of the study area soil are given in Tab. 1. 


\section{Irrigation treatments}

Soil moisture was measured at respectively 30, 60 and $90 \mathrm{~cm}$ soil depths with a digital tensiometer (Soilspec digital tensiometer, JGK TECH, Australia) before each irrigation. There were used three tensiometers for each replication (one each at 30,60 and $90 \mathrm{~cm}$ soil depth). Drip irrigation system was used in this study. Emitter flow rate, emitter spacing and main pipe diameters used in the system were calculated according to Yildirim (2005). The lateral pipes with $16 \mathrm{~mm}$ diameter were laid along both sides of each row of trees. Emitter spacing on laterals were 0.50 $m$ with all emitters having a discharge rate of $4 \mathrm{llh}^{-1}$.

Irrigation interval was considered as 4 days in all treatments. In the study, 6 different treatments were included; i.e., none deficit irrigation $\left(T_{1}\right)$, deficit irrigation during growing season (continuous deficit irrigation) $\left(\mathrm{T}_{2}\right)$, deficit irrigation between the $40^{\text {th }}$ and $70^{\text {th }}$ DAFB $\left(\mathrm{T}_{3}\right)$, deficit irrigation between the $70^{\text {th }}$ and $100^{\text {th }} \mathrm{DAFB}\left(\mathrm{T}_{4}^{3}\right)$, deficit irrigation between the $100^{\text {th }}$ and $130^{\text {th }} \mathrm{DAFB}\left(\mathrm{T}_{5}\right)$ and deficit irrigation between the $130^{\text {th }}$ and $160^{\text {th }}$ DAFB $\left(\mathrm{T}_{6}\right)$. Plant pan coefficient $\left(\mathrm{K}_{\mathrm{cp}}\right)$ was considered to be 1.0 in $\mathrm{T}_{1}$ during growing season. However, it was 0.25 during growing season in $\mathrm{T}_{2}$. The Kcp was used as 0.25 in deficit irrigation periods after full bloom in $\mathrm{T}_{3}, \mathrm{~T}_{4}, \mathrm{~T}_{5}$ and $\mathrm{T}_{6}$. Outside the periods mentioned above, $\mathrm{K}_{\mathrm{cp}}$ was taken as 1.0 for calculations.

Unlike some other fruit varieties such as pear and peach, phenological stages of apple shoot and fruit development are not clearly separate (Chalmers, 1989). For this reason, 30-day short-term water deficit was applied in this study. Deficit irrigation applications were launched after the $40^{\text {th }}$ and $45^{\text {th }}$ days after full bloom. Cell division phase has a significant effect on fruit size and lasts for 4-5 weeks after full bloom for apple (Felmann, 1996). Due to the fact that fruit cell division is accepted to be completed at the end of these days, deficit irrigation applications were launched following these days.

\section{Calculating of Irrigation Water and Plant Water Consumption}

For each treatment, evapotranspiration was calculated according to James (1988):

$$
\mathrm{ET}=\mathrm{I}+\mathrm{R}+\mathrm{Cr}-\mathrm{Dp}-\mathrm{Rf} \pm \Delta s
$$

where ET is the evapotranspiration $(\mathrm{mm}), \mathrm{I}$ is irrigation water $(\mathrm{mm}), \mathrm{R}$ is the rainfall $(\mathrm{mm}), \mathrm{C}_{\mathrm{r}}$ is the capillary rise $(\mathrm{mm}), \mathrm{D}$ is the water loss by deep percolation $(\mathrm{mm}), \mathrm{R}$ is the surface run-off $(\mathrm{mm})$, and $\Delta s$ is the change in profile soil water content $(\mathrm{mm}) . \mathrm{C}_{\mathrm{r}}$ values were considered as zero as there were not any ground water problems in the area. $R_{f}$ was also not taken into account because the total water amount applied through was measured for each irrigation. The precipitation was measured after every raining day with a pluviometer positioned near the Class-A pan. Soil moisture content was measured prior each irrigation and the water amount applied during each irrigation was recorded. During the next irrigation, the soil moisture was measured and the difference was recorded as "plant water consumption" of that treatment. Irrigation quantity in Eq. (1) was calculated for each treatment of drip irrigation according to Ertek and Kanber (2003):

$$
I=E_{p a n} \times K_{c p} \times P
$$

where $\mathrm{I}$ is irrigation water $(\mathrm{mm}), \mathrm{E}_{\mathrm{pan}}$ is the cumulative evaporation quantity at 4 days irrigation interval $(\mathrm{mm})$, $\mathrm{K}_{\mathrm{cp}}$ is the plant-pan coefficient, and $\mathrm{P}$ is wetting area. Wetting area was calculated as the ratio of the surface area shaded by trees at noon to the surface area allocated to one tree and found to be $37 \%$ (0.37). Evaporation quantity between irrigation intervals was measured everyday with a Class-A pan positioned near the plots. Available moisture at $0-90 \mathrm{~cm}$ soil depth was reached to field capacity at the end of full bloom; after that date, programmed irrigation was initiated (Köksal et al., 1999). The first irrigation dates were May 14, May 8 and May 14 respectively while the last irrigation dates were September 27, September 25 and September 23 respectively for 2010, 2011 and 2012.

\section{Measurements of vegetative growth, yield and fruit quality \\ Vegetative growth: One-year shoots from the main} branch were selected for each tree per replications and their lengths $(\mathrm{cm})$ and diameters $(\mathrm{mm})$ measured every January. Shoot length and diameter were determined by digital calliper. Shoot diameters were measured from basal parts of the shoots (Köksal et al., 1999).

Yield and fruit quality: Fruits of five trees selected from each replication were harvested and weighted. Then the yield was determined in terms of $\mathrm{kg} \mathrm{da}^{-1}$. Harvesting dates were October 18, 24 and 22 in 2010, 2011 and 2012, respectively. For fruit assessments, samples of 15 fruits in one tree for per replicate were selected. Total 45 fruits per treatment were harvested for quality analyses at the commercial harvest. Physical (fruit diameter, fruit length, fruit weight, flesh firmness, and skin colour) and chemical (TSS; total soluble solids) analyses were conducted on the selected fruits (Tab. 2). Fruit diameter was used as the quality criterion for classification. The fruits were graded on a commercial size grade ranging from 50 to $95 \mathrm{~mm}$. The percentage of fruit in various size categories was determined as extra $(>75 \mathrm{~mm})$, class $1(68-75 \mathrm{~mm})$, class $2(60$ $68 \mathrm{~mm}$ ) and other (<60 mm) (Küçükyumuk et al., 2012).

\section{Experimental design and statistical analysis}

This study was designed according to Randomized Blocks Experimental Design with three replications. Plots consisted of two rows with 9 trees each (i.e. 18 trees). One row was left as extra row between two plots. From nine trees in one row in each plot, four trees were not considered (two from the top and two from the end). So, during 
512

harvest, 5 trees were taken into account. The analysis of variance (ANOVA) test for the data was conducted with JUMP software program and differences among treatments were compared by means using LSD test.

\section{Results and discussion}

\section{Irrigation water and plant water consumption}

The lowest irrigation water was applied to $\mathrm{T}_{2}$ treatment during this study. The lowest plant water consumption was obtained from this treatment. On the other hand, $T_{1}$ treatment had the highest values. In other treatments with periodic deficit irrigation, irrigation water applied was lower to the amount of deficit, and plant water consumption was lower (Tab. 3). According to $\mathrm{T}_{1}$ treatment, periodic deficit irrigation treatments saved irrigation water and these ranged from 12.4 to $19.7 \%$ in 2010 , from 12.4 to $18.9 \%$ in 2011 and from 11.6 to $20.9 \%$ in 2012 . Some of researchers reported that, periodic deficit irrigation treatments decreased irrigation water and plant water consumption in apple (Mills et al., 1997; Petillo et al., 2009).

\section{Vegetative growth}

The effect of the treatments on vegetative development (shoot length and shoot diameter) was highly significantly in the study $(\mathrm{p}<0.01)$ (Tab. 4). The highest shoot length and shoot diameter values were obtained from $T_{1}$ treatment and $\mathrm{T}_{2}$ had the lowest values. On the other hand, the effects of periodic deficit irrigation were determined to be different depending on the time of deficit. It was observed that, compared to other periodic deficit irrigation treatments $\left(\mathrm{T}_{5}\right.$ and $\left.\mathrm{T}_{6}\right)$, deficit irrigation treatments in an early period such as $T_{3}$ and $T_{4}$ had more negative effects on vegetative development. As a matter of fact, O'Connel and Goodwin (2007) and Bianco and Francaviglia (2012) reported that deficit irrigation reduced shoot development and consequently vegetative development.

\section{Yield and fruit quality}

All deficit irrigation treatments significantly reduced fruit yield in all years $(\mathrm{p}<0.01)$ (Tab. 5). The lowest yield values were found in $T_{2}$ treatment. The reason may be that the effect of 2-year stress conditions became more effective in the $3^{\text {rd }}$ year. The yield obtained from the treatment with deficit irrigation between the $40^{\text {th }}$ and $70^{\text {th }}$ DAFB $\left(\mathrm{T}_{3}\right)$ was closest to that obtained from none deficit irrigation treatment during the study $\left(T_{1}\right)$. Decreasing in yield was obtained in $T_{3}, T_{4}, T_{5}$ and $T_{6}$, which included periodic deficit irrigation. Deficit irrigation treatments in different periods had different effects on yield and fruit quality. The reason for this may be that apple have three development stages with different speeds (Stage I: 56 DAFB, fruit development is slow; Stage II: 56-151 DAFB, fruit development is fast; Stage III: 151-180 DAFB fruit development is slow) (Atay, 2007). In order that $T_{3}$ treatment was applied in Stage I, deficit irrigation in $\mathrm{T}_{3}^{3}$ treatment affected less negatively on yield and fruit quality (fruit diameter, marketable yield, red colour density etc.). In the same time, this period also meets to the period right after the end of the cell division phase which has an important effect on fruit size in apple (Felmann, 1996). It was reported that the available water amounts in soil plays an active role in root activity (Bergamini et al., 1988). Since different water amounts were applied to treatments, soil water at effective root depth varied and thus water amounts consumed by apple trees differed. The difference proved its effect on yield. This result revealed that deficit water applications had significant effects on the yield of M9 rootstock apple trees even if they were short-term deficit water applications. Also it was determined that knowing the application period of deficit irrigation was fundamental. It was reported that, periodic deficit irrigation applications affected and reduced yield in apple trees (Mpelasoka et al., 2001; Petillo et al., 2009; Girona et al., 2010).

The results of fruit diameter, fruit length and fruit weight are in (Tab. 6). The fruit diameter measurements were statistically significant $(\mathrm{p}<0.01)$ among the treatments for three years. While the highest values were obtained in $T_{1}, T_{2}$ had the lowest values. Deficit irrigation treatments in different periods had different effects on fruit diameter. Among the treatments with periodic deficit irrigation, the highest value was obtained from $T_{3}$ while the lowest values were observed in $T_{4}$. $T_{1}$ had the highest fruit length and fruit weight values, whereas the lowest values were determined in $T$. The more soil water affects the amount of water received by roots. It affects both apple tree yield and fruit quality (fruit diameter, length, weight, etc.). It was determined that deficit irrigation caused decreasing for fruit diameter values. Decreasing for fruit diameter in $T_{2}$ treatment was different based on periodic deficit irrigation treatments. The fruits of $T_{2}$ treatment had a smaller fruit diameter. The fact that fruit diameter values were correlated with plant water consumption at a significance level of $1 \%(\mathrm{p}<0.01)$ supports these results (Fig. 1). O'Connel and Goodwin (2007) and Zaliha and Singh (2009b) reported that, compared to the applications without any water deficit, fruit diameter decreased in deficit irrigation applications. Bergamini et al. (1990) reported for Golden Delicious apple cultivar that fruit diameter increased as the irrigation water amount increased. Similar effects were observed on fruit length and fruit weight. In addition, Talluto et al. (2008) and Girona et al. (2010) informed that deficit irrigation resulted in a decrease in fruit weight. It was detected that the effects of $T_{2}$ treatment were different from that of the deficit irrigation applied in different periods. However, all deficit irrigation treatments were determined to cause a decreasing for fruit diameter, fruit length and fruit weight. It was observed that in $\mathrm{T}_{1}$ and $\mathrm{T}_{3}$, the results of fruit diameter, fruit length and fruit weight were close to one another.

Fruit growth (diameter, length, weight) was determined to be closely associated with the amounts of plant 

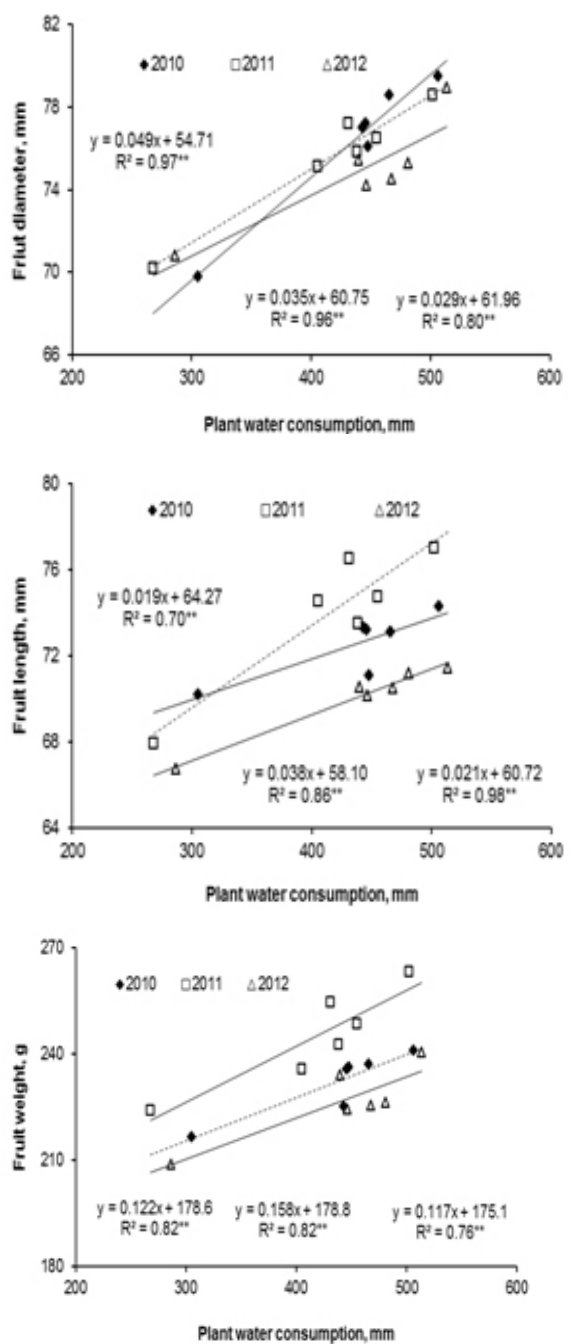

Fig. 1. ET-fruit diameter, ET-fruit length and ET-fruit weight relationship

water consumption. Fig. 1 shows the relationships between plant water consumption and fruit diameter, fruit length and fruit weight (at a significance level of 1\%). It was determined that positive linear relationships between plant water consumption and these parameters.

During the experiment, the treatments were determined to have significant effects on fruit flesh firmness values $(p<0.01)$ (Tab. 7). The highest values were obtained from $T_{2}$. On the other hand, none deficit irrigation $\left(T_{1}\right)$ had the lowest results. Deficit irrigation applied in different periods had different effects on fruit flesh firmness. Among periodic deficit irrigation treatments, $T_{4}$ had the highest flesh firmness values. Similarly, the deficit irrigation treatments increased fruit flesh firmness, as previously reported by other authors (Mpelasoka et al., 2001; Zaliha and Singh, 2009a). According to the TSS results, differences at a significance level of $1 \%$ were found among the treatments. The highest TSS value was obtained from $T_{2}$ whereas the lowest TSS value was determined in $\mathrm{T}_{1}$ ( $\mathrm{Tab}$. 7). It was found that fruit flesh firmness and TSS values were close in $T_{1}$ and $T_{3}$. Different deficit irrigation strategies caused to an increasing for TSS values. Mpelasoka et al. (2001) and Leib et al. (2006) reported that deficit irrigation applications in apple increased TSS values. In addition, Zaliha and Singh (2009a) indicated that TSS increased in short-term continuous deficit irrigation compared to none deficit irrigation but decreased in continuous deficit irrigation applied shortly before harvest. These results demonstrated that different water deficit application periods led to different TSS values.

Inverse linear relationships $(p<0.01)$ were determined between plant water consumption and fruit flesh firmness and between fruit diameter and fruit flesh firmness (Fig. 2). As plant water consumption increased, fruit flesh firmness values decreased. A similar relationship was found between fruit diameter and fruit flesh firmness. While fruit diameter increased fruit flesh firmness decreased.

There were statistically significant differences among fruit skin colour values (Tab. 8). A negative correlation was determined between red colour and fruit skin brightness values (data not shown). Red colour(a) increased
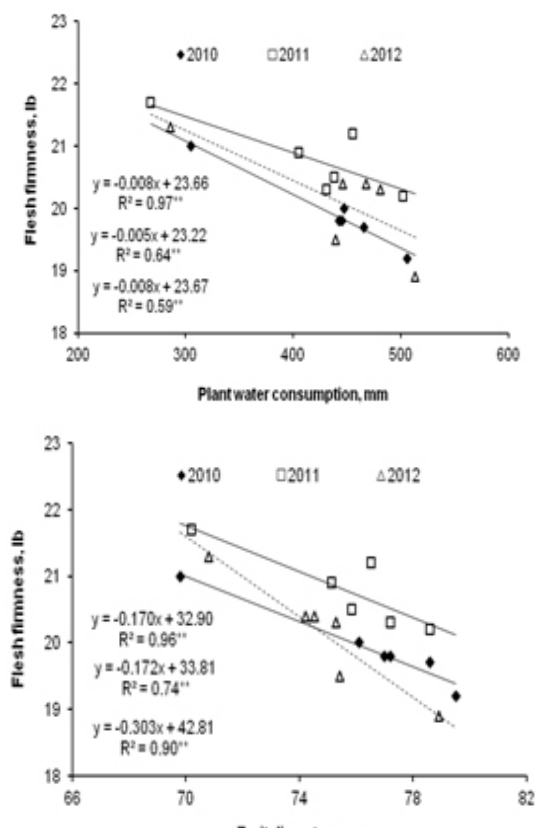

Fig. 2. ET-flesh firmness and fruit diameter-flesh firmness relationship

while the fruit flesh brightness $\left(L^{*}\right)$ decreased. The highest $\mathrm{L}^{*}$ values were obtained from $\mathrm{T}_{4}$ whereas the lowest $\mathrm{L}^{*}$ values were found in $T_{2}$. Continuous deficit irrigation, $T_{2}$, had the highest $\mathrm{a}^{*}$ (red colour) values. However, the lowest $\mathrm{a}^{*}$ values were obtained from $\mathrm{T}_{4}$. On the other hand, deficit irrigation between the $70^{\text {th }}$ and $100^{\text {th }}$ DAFB led to a decrease in apple red colour. Deficit irrigation that was applied to $\mathrm{T}_{4}$ caused a decrease the fruit skin red colour whereas $T_{3}$ had a positive effect on the red colour. These results can be due to the effects of deficit irrigation on the shoot length values. Actually, the highest red colour values were found both in $T_{2}$ and $T_{3}$ treatments that was deter- 
514

mined as the lowest shoot length values. The results for skin colour in the study were similar to those of Mills et al. (1997); Kilili et al. (1996); Zaliha and Singh (2009a), which reported that deficit irrigation applications led to the increase of red colour.

Due to the effect of deficit irrigation treatments on fruit diameter, marketable yield differences were observed among treatments (Tab. 9). As one of the important criteria in marketing, marketable yield was negatively affected by deficit irrigation applications. $T_{1}$ had the highest marketable yield (extra and class 1 ) and followed by $\mathrm{T}_{3}$. There were the lowest extra and class 1 ratio in $T_{2}$ treatment.
Among the treatments with periodic deficit irrigation, $\mathrm{T}_{3}$ had the highest marketable yield values. The treatment with the highest Class 2 ratio was determined to be $T_{2}$. It was found that $T_{3}$ deficit irrigation treatment had the minimum negative effect on marketable yield. Girona et al. (2010) reported that, compared to none deficit irrigation, different deficit irrigation applications decreased marketable yield.

Tab. 1. Soil characteristics of trial plots

\begin{tabular}{ccccccccc}
\hline Depth $(\mathrm{cm})$ & $\begin{array}{c}\gamma \\
\left(\mathrm{g} / \mathrm{cm}^{3}\right)\end{array}$ & $\begin{array}{c}\mathrm{FC} \\
(\%)\end{array}$ & WP $(\%)$ & AWHC $(\mathrm{mm})$ & $\begin{array}{c}\text { Salinity } \\
(\mathrm{ECx} 106)\end{array}$ & $\mathrm{pH}$ & $\begin{array}{c}\text { Organic } \\
\text { matter }(\%)\end{array}$ & Texture \\
$0-30$ & 1.46 & 24.2 & 11.5 & 55.6 & 175 & 8.1 & 1.80 & Clay loam \\
$30-60$ & 1.38 & 25.1 & 13.1 & 49.7 & 125 & 7.9 & 2.70 & Clay loam \\
$60-90$ & 1.41 & 24.3 & 12.2 & 51.2 & 130 & 8.0 & 2.75 & Clay loam \\
\hline
\end{tabular}

Tab. 2. Quality parameters and measurements

\begin{tabular}{lll}
\hline \multicolumn{1}{c}{ Parameters } & Unit & \multicolumn{1}{c}{ Measurements } \\
$\begin{array}{l}\text { Fruit diameter } \\
\text { Fruit length }\end{array}$ & $\mathrm{mm}$ & digital calliper was used with $0.01 \mathrm{~mm}$ resolution \\
Fruit weight & $\mathrm{mm}$ & digital calliper was used with $0.01 \mathrm{~mm}$ resolution \\
Fruit flesh firmness & $\mathrm{g}$ & $\begin{array}{l}\text { digital balance }(\mathrm{Scaltec}, \mathrm{SBA}-51) \text { to } 0.01 \mathrm{~g} \text { sensitivity } \\
\text { determined on two opposite sides of each fruit, using a hand held penetrometer } \\
\text { fitted with a } 11 \mathrm{~mm} \text { diameter probe }\end{array}$ \\
Fruit skin colour & $\mathrm{lb}$ & $\begin{array}{l}\text { measured on the two opposite sides of each fruit with a Minolta Chroma meter } \\
\text { model CR-400. The data obtained were evaluated CIELAB colour scale }\end{array}$ \\
\hline Total soluble solids content & $\mathrm{L}^{*} \mathrm{a}^{*}$ & LCD Digital bench refractometer
\end{tabular}

Tab. 3. Irrigation water, plant water consumption, evaporation and precipitation values of the study

\begin{tabular}{|c|c|c|c|c|c|c|}
\hline \multirow{2}{*}{ Treatments } & \multicolumn{2}{|c|}{2010} & \multicolumn{2}{|c|}{2011} & \multicolumn{2}{|c|}{2012} \\
\hline & $\mathrm{I}(\mathrm{mm})$ & $\mathrm{ET}(\mathrm{mm})$ & $\mathrm{I}(\mathrm{mm})$ & $\mathrm{ET}(\mathrm{mm})$ & $\mathrm{I}(\mathrm{mm})$ & $\mathrm{ET}(\mathrm{mm})$ \\
\hline $\mathrm{T}_{1}$ & 370.5 & 506.2 & 361.0 & 501.9 & 395.1 & 513.5 \\
\hline $\mathrm{T}_{2}$ & 120.0 & 305.1 & 108.4 & 267.7 & 119.3 & 286.2 \\
\hline $\mathrm{T}_{3}$ & 324.6 & 465.4 & 308.8 & 431.0 & 335.0 & 439.4 \\
\hline $\mathrm{T}_{4}$ & 303.1 & 447.4 & 292.7 & 405.2 & 312.7 & 446.3 \\
\hline $\mathrm{T}_{5}^{4}$ & 297.8 & 442.8 & 300.6 & 438.1 & 320.3 & 467.4 \\
\hline $\mathrm{T}_{6}$ & 322.5 & 445.5 & 316.5 & 455.0 & 349.3 & 480.9 \\
\hline Evaporation (mm) & \multicolumn{2}{|c|}{890.1} & \multicolumn{2}{|c|}{909.9} & \multicolumn{2}{|c|}{984.8} \\
\hline Precipitation $(\mathrm{mm})$ & \multicolumn{2}{|c|}{80.5} & \multicolumn{2}{|c|}{87.2} & \multicolumn{2}{|c|}{114.9} \\
\hline
\end{tabular}

Tab. 4. Shoot length and shoot diameter in 2010, 2011 and 2012

\begin{tabular}{|c|c|c|c|c|c|c|}
\hline \multirow{2}{*}{ Treatments } & \multicolumn{3}{|c|}{ Shoot length $(\mathrm{cm})$} & \multicolumn{3}{|c|}{ Shoot diameter (mm) } \\
\hline & 2010 & 2011 & 2012 & 2010 & 2011 & 2012 \\
\hline $\mathrm{T}_{1}$ & $62.78^{a^{* *}}$ & $57.42^{a * *}$ & $54.42^{a^{* *}}$ & $7.83^{b * *}$ & $8.41^{\mathrm{a} * *}$ & $7.39^{a^{* *}}$ \\
\hline $\mathrm{T}_{2}$ & $42.87^{d}$ & $41.67^{c}$ & $38.86^{c}$ & $6.30^{c}$ & $5.95^{c}$ & $4.99^{c}$ \\
\hline $\mathrm{T}_{3}$ & $48.69^{\mathrm{cd}}$ & $46.16^{b c}$ & $43.96^{\mathrm{bc}}$ & $7.29^{b}$ & $7.53^{b}$ & $6.60^{\mathrm{b}}$ \\
\hline $\mathrm{T}_{4}$ & $53.69^{b c}$ & $51.84^{\mathrm{ab}}$ & $48.69^{\mathrm{ab}}$ & $6.36^{c}$ & $7.55^{b}$ & $6.68^{b}$ \\
\hline $\mathrm{T}_{5}$ & $55.20^{\mathrm{bc}}$ & $52.67^{a}$ & $50.17^{\mathrm{ab}}$ & $7.48^{b}$ & $7.86^{\mathrm{ab}}$ & $6.92^{\mathrm{ab}}$ \\
\hline $\mathrm{T}_{6}$ & $58.40^{\mathrm{ab}}$ & $54.24^{\mathrm{a}}$ & $51.10^{\mathrm{a}}$ & $9.05^{\mathrm{a}}$ & $8.02^{\mathrm{ab}}$ & $7.15^{\mathrm{ab}}$ \\
\hline
\end{tabular}

${ }^{* *} \mathrm{P}<0.01$, Values with common letters do not differ significantly. 
Tab. 5. Effects of deficit irrigation treatments on yield parameters

\begin{tabular}{lccc}
\hline & 2010 & 2011 & 2012 \\
& & Yield $\left(\mathrm{kg} \mathrm{da}^{-1}\right)$ & $7171.1^{\mathrm{a} * *}$ \\
$\mathrm{~T}_{1}$ & $5875.1^{\mathrm{a} * *}$ & $6107.2^{\mathrm{a} * *}$ & $3216.7^{\mathrm{c}}$ \\
$\mathrm{T}_{2}$ & $389.5^{\mathrm{d}}$ & $3759.0^{\mathrm{c}}$ & $6377.8^{\mathrm{ab}}$ \\
$\mathrm{T}_{3}$ & $5518.8^{\mathrm{ab}}$ & $5406.9^{\mathrm{ab}}$ & $5795.5^{\mathrm{b}}$ \\
$\mathrm{T}_{4}$ & $5038.5^{\mathrm{bc}}$ & $4853.6^{\mathrm{b}}$ & $5814.4^{\mathrm{b}}$ \\
$\mathrm{T}_{5}$ & $4675.0^{\mathrm{c}}$ & $5169.5^{\mathrm{b}}$ & $6209.5^{\mathrm{ab}}$ \\
\hline
\end{tabular}

${ }^{* *} \mathrm{P}<0.01$, Values with common letters do not differ significantly.

Tab. 6. Effects of deficit irrigation treatments on some fruit parameters

\begin{tabular}{|c|c|c|c|c|c|c|c|c|c|}
\hline \multirow{2}{*}{ 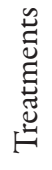 } & \multicolumn{3}{|c|}{ Fruit diameter $(\mathrm{mm})$} & \multicolumn{3}{|c|}{ Fruit length $(\mathrm{cm})$} & \multicolumn{3}{|c|}{ Fruit weight (g) } \\
\hline & 2010 & 2011 & 2012 & 2010 & 2011 & 2012 & 2010 & 2011 & 2012 \\
\hline $\mathrm{T}_{1}$ & $79.50^{a^{* *}}$ & $78.64^{a^{* *}}$ & $78.91^{\mathrm{a}^{* *}}$ & $74.31^{\mathrm{a}^{*}}$ & $77.02^{a * *}$ & $71.41^{\mathrm{a}^{* *}}$ & $241.1^{\mathrm{a}^{*}}$ & $263.2^{a^{* *}}$ & $240.4^{a^{* *}}$ \\
\hline $\mathrm{T}_{2}$ & $69.81^{\mathrm{d}}$ & $70.39^{d}$ & $70.80^{c}$ & $70.22^{c}$ & $67.91^{b}$ & $66.72^{b}$ & $216.6^{b}$ & $223.9^{d}$ & $208.8^{b}$ \\
\hline $\mathrm{T}_{3}$ & $78.60^{\mathrm{ab}}$ & $76.28^{b}$ & $75.42^{b}$ & $73.31^{\mathrm{ab}}$ & $76.53^{a}$ & $70.53^{a}$ & $237.1^{a}$ & $254.7^{\mathrm{ab}}$ & $234.0^{\mathrm{a}}$ \\
\hline $\mathrm{T}_{4}$ & $76.11^{c}$ & $74.14^{c}$ & $74.21^{b}$ & $71.10^{b c}$ & $74.52^{a}$ & $70.15^{a}$ & 236.3 a & $235.7^{\mathrm{cd}}$ & $224.2^{a b}$ \\
\hline $\mathrm{T}_{5}^{4}$ & $76.98^{b c}$ & $75.53^{b c}$ & $74.52^{b}$ & $73.12^{\mathrm{ab}}$ & $73.51^{\mathrm{a}}$ & $70.51^{a}$ & $225.1^{\mathrm{ab}}$ & $242.6^{\mathrm{bcd}}$ & $225.4^{\mathrm{ab}}$ \\
\hline $\mathrm{T}_{6}$ & $77.20^{\mathrm{bc}}$ & $74.89^{b c}$ & $75.29^{b}$ & $73.19^{\mathrm{ab}}$ & $74.76^{a}$ & $71.20^{\mathrm{a}}$ & $235.6^{a}$ & $248.4^{\mathrm{abc}}$ & $226.3^{a}$ \\
\hline
\end{tabular}

${ }^{* *} \mathrm{P}<0.01{ }^{*} \mathrm{P}<0.05$, Values with common letters do not differ significantly.

Tab. 7. Effects of deficit irrigation treatments on flesh firmness and soluble solids content

\begin{tabular}{|c|c|c|c|c|c|c|}
\hline \multirow{2}{*}{ 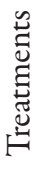 } & \multicolumn{3}{|c|}{ Flesh firmness (lb) } & \multicolumn{3}{|c|}{ Total soluble solids content (\%) } \\
\hline & 2010 & 2011 & 2012 & 2010 & 2011 & 2012 \\
\hline T1 & $19.2^{b * *}$ & $20.2^{\mathrm{c**}}$ & $18.9^{\mathrm{c*}}$ & $12.6^{\mathrm{b} * *}$ & $11.72^{\mathrm{c} * *}$ & $11.93^{c *}$ \\
\hline $\mathrm{T} 2$ & $21.0^{\mathrm{a}}$ & $21.7^{a}$ & $21.3^{a}$ & $13.8^{\mathrm{a}}$ & $12.80^{a}$ & $12.93^{a}$ \\
\hline T3 & $19.7^{\mathrm{b}}$ & $20.3^{c}$ & $19.5^{\mathrm{c}}$ & $12.8^{\mathrm{b}}$ & $11.93^{\mathrm{c}}$ & $12.59^{\mathrm{ab}}$ \\
\hline $\mathrm{T} 4$ & $20.0^{\mathrm{b}}$ & $21.2^{\mathrm{abc}}$ & $20.6^{\mathrm{b}}$ & $13.0^{\mathrm{b}}$ & $12.02^{\mathrm{bc}}$ & $12.36^{\mathrm{bc}}$ \\
\hline T5 & $19.8^{\mathrm{b}}$ & $20.5^{\mathrm{bc}}$ & $20.3^{\mathrm{b}}$ & $12.9^{\mathrm{b}}$ & $12.43^{\mathrm{ab}}$ & $12.45^{b}$ \\
\hline T6 & $19.8^{\mathrm{b}}$ & $20.9^{\mathrm{ab}}$ & $20.3^{\mathrm{b}}$ & $13.2^{\mathrm{b}}$ & $12.20^{\mathrm{bc}}$ & $12.58^{\mathrm{ab}}$ \\
\hline
\end{tabular}

${ }^{* *} \mathrm{P}<0.01$, Values with common letters do not differ significantly.

Tab. 8. Skin colour per irrigation treatments

\begin{tabular}{|c|c|c|c|c|c|c|}
\hline \multirow{2}{*}{ 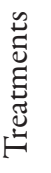 } & \multicolumn{2}{|c|}{2010} & \multicolumn{2}{|c|}{2011} & \multicolumn{2}{|c|}{2012} \\
\hline & $\mathrm{L}$ & a & $\mathrm{L}$ & a & $\mathrm{L}$ & a \\
\hline $\mathrm{T}_{1}$ & $51.49 \mathrm{abc} *$ & $17.14^{\mathrm{abc} * *}$ & $51.15^{a b *}$ & $17.34^{a b c * *}$ & $50.90^{a b *}$ & $18.06^{\mathrm{abc} * *}$ \\
\hline $\mathrm{T}_{2}$ & $48.79^{c}$ & $20.44^{a}$ & $49.09^{b}$ & $20.42^{a}$ & $47.61^{b}$ & $20.61^{a}$ \\
\hline $\mathrm{T}_{3}$ & $49.56^{b c}$ & $19.89^{\mathrm{ab}}$ & $49.25^{b}$ & $19.56^{\mathrm{ab}}$ & $49.67^{\mathrm{ab}}$ & $19.93^{\mathrm{ab}}$ \\
\hline $\mathrm{T}_{4}$ & $54.14^{a}$ & $13.87^{c}$ & $52.76^{a}$ & $13.86^{c}$ & $53.15^{a}$ & $14.88^{c}$ \\
\hline $\mathrm{T}_{5}$ & $52.55^{\mathrm{ab}}$ & $14.38^{c}$ & $51.50^{\mathrm{ab}}$ & $15.98^{\mathrm{bc}}$ & $52.86^{a}$ & $15.39^{c}$ \\
\hline $\mathrm{T}_{6}$ & $52.00^{a b c}$ & $15.95^{b c}$ & $52.50^{a}$ & $16.19^{b c}$ & $51.21^{\mathrm{ab}}$ & $16.36^{b c}$ \\
\hline
\end{tabular}

${ }^{* *} \mathrm{P}<0.01{ }^{*} \mathrm{P}<0.05$, Values with common letters do not differ significantly 


\begin{tabular}{|c|c|c|c|c|c|c|c|c|c|c|c|c|}
\hline \multirow{2}{*}{ 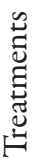 } & \multicolumn{4}{|c|}{2010} & \multicolumn{4}{|c|}{2011} & \multicolumn{4}{|c|}{2012} \\
\hline & 䔍 & $\frac{\overrightarrow{\tilde{s}}}{\tilde{U}}$ & $\begin{array}{c}\sim \\
\tilde{\tilde{J}} \\
\tilde{U}\end{array}$ & $\frac{\dot{\Xi}}{\dot{\Xi}}$ & 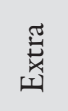 & $\frac{\overrightarrow{\tilde{\Xi}}}{\widetilde{U}}$ & $\begin{array}{c}N \\
\tilde{\tilde{J}} \\
\tilde{U}\end{array}$ & $\frac{\dot{U}}{\dot{H}}$ & 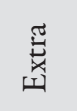 & $\frac{\widetilde{\tilde{U}}}{\tilde{U}}$ & $\begin{array}{l}N \\
\underset{\tilde{\mho}}{U}\end{array}$ & $\frac{\dot{U}}{\dot{0}}$ \\
\hline $\mathrm{T}_{1}$ & 90.0 & 10.0 & 0 & 0 & 76.7 & 23.3 & 0 & 0 & 86.7 & 13.3 & 0 & 0 \\
\hline $\mathrm{T}_{2}$ & 16.7 & 43.3 & 33.3 & 6.7 & 10.0 & 69.9 & 20.1 & 0 & 20.0 & 53.3 & 26.7 & 0 \\
\hline $\mathrm{T}_{3}$ & 83.3 & 16.7 & 0 & 0 & 66.6 & 30.0 & 3.4 & 0 & 56.7 & 43.3 & 0 & 0 \\
\hline $\mathrm{T}_{4}$ & 50.0 & 50.0 & 0 & 0 & 40.0 & 56.6 & 3.4 & 0 & 43.3 & 53.3 & 3.4 & 0 \\
\hline $\mathrm{T}_{5}$ & 80.0 & 16.7 & 3.3 & 0 & 53.3 & 43.3 & 3.4 & 0 & 53.3 & 36.7 & 10.0 & 0 \\
\hline $\mathrm{T}_{6}$ & 70.0 & 26.7 & 3.3 & 0 & 46.6 & 46.6 & 6.8 & 0 & 43.3 & 53.3 & 3.4 & 0 \\
\hline
\end{tabular}

Extra $(>75 \mathrm{~mm})$, Class $1(68-75 \mathrm{~mm})$, Class $2(60-68 \mathrm{~mm})$, Other $(<60 \mathrm{~mm})$.

\section{Conclusions}

According to the results obtained, it was determined that short-term (30 days) deficit irrigation during growth season resulted in decrease for vegetative development and yield but saving irrigation water. The deficit water treatment between the $40^{\text {th }}$ and $70^{\text {th }}$ DAFB $\left(\mathrm{T}_{3}\right)$ not only saved irrigation water but also negatively affected yield and marketable yield least. The apples that have the highest red colour density were obtained from that treatment except $\mathrm{T}_{2}$. For more efficient use of water resources in case of limited irrigation water, $\mathrm{T}_{3}$ treatment may be recommended to apple growers because it not only saves water but also negatively affects yield and fruit quality least.

\section{Acknowledgement}

This study was summarized partially from the research project supported by the General Directorate of Agricultural Research and Policy, Food, Agriculture and Livestock Ministry, Turkey.

\section{References}

Anonymous (2012). Data of Apple Industry. Food, Agriculture and Livestock Ministry, General Directorate of Agricultural Research and Policy, Fruit Research Station, Eğirdir, Isparta, Turkey, pp. 31.

Atay E (2007). Determination of Fruit Growth and Development Some Apple Varieties on MM 106 Rootstock. Selçuk University Graduate School of Natural and Applied Sciences, MS Thesis, 68 p., Konya.

Behboudian MH, Marsal J, Girona J, Lopez G (2011). Quality and yield responses of deciduous fruits to reduced irrigation. Hortic Rev 38:149-189.

Bergamini A, Angelini S, Bigaran F (1988). Effect of different rootstocks and of cropping of trees on Golden Delicious clone. B. Societa Orticola Italiano 545-553.

Bergamini A, Angelini S, Bigaran F (1990). Influence of 4 different rootstocks on the stomal resistance and leaf water po- tential of Golden Delicious Clone B (Virus T Ree) subjected to different irrigation regimes. Societa Orticola Italiana 1988:533-544 (Hort. Abstr. 60, 2256).

Bianco RL, Francaviglia D (2012). Comparative response of 'Gala' and 'Fuji' apple trees to deficit irrigation: placement versus volume effects. Plant and Soil 357(1-2):41-58.

Chalmers DJ, Mitchell PD, Van Heek L (1981). Control of peach tree growth and productivity by regulated water supply, tree density, and summer pruning. Journal of American Society Hort Sci 106:307-312.

Chalmers DJ (1989). A physiological examination of regulated deficit irrigation. N Z J Agricultural Science 23:44-48.

Dennis FG (1996). Fruit Development. In Tree Fruit Physiology: Growth and Development Books, Good Fruit Grower, Washington, pp. 107-116.

Ertek A, Kanber R (2003). Effects of different irrigation programs on boll number and abscission percentage of cotton. Agricultural Water Management 60(1):1-11.

Felmann JK (1996). Pome fruit quality in relation to environmental stress. In Tree Fruit Physiology: Growth and Development Books, Good Fruit Grower, Washington, pp. 127131.

Fereres E, Goldhamer D (1990). Irrigation of deciduous fruit and nut trees. In: Irrigation of Agricultural Crops. ASA Monograph No. 30. American Society of Agronomy, Madison, WI, pp. 987-1017.

Girona J, Behboudian MH, Mata M, Del Campo J, Marsal J (2010). Exploring six reduced irrigation options under water shortage for 'Golden Smoothee' apple: responses of yield components over three years. Agricultural Water Management 98:370-375.

James LG (1988). Principles of Farm Irrigation System Design. John Wiley and Sons. Inc., New York, USA, pp. 543.

Kilili AW, Behboudian MH, Mills TM (1996). Composition and quality of 'Braeburn' apples under reduced irrigation. Sci Hortic 67:1-11.

Köksal Aİ, Dumanoğlu H, Güneş N, Yıldırım, O, Kadayıfçı A (1999). Effects of different irrigation methods and regimes 
on vegetative growth, fruit yield and quality of apple trees. Turkish Journal of Agriculture and Forestry 23:909-920.

Küçükyumuk C, Kaçal E, Ertek A, Öztürk G, Kukul Kurttaş YS (2012). Pomological and vegetative changes during transition from flood irrigation to drip irrigation: Starkrimson Delicious apple variety. Scientia Horticulturae 136:17-23.

Leib BG, Caspari HW, Redulla CA, Andrews PK, Jabro JJ (2006). Partial rootzone drying and deficit irrigation of 'Fuji' apples in a semi-arid climate. Irrigation Science 24(2):8599.

Mills TM, Behboudian MH, Clothier BE (1997). The diurnal and seasonal water relations, and composition, of 'Braeburn' apple fruit under reduced plant water status. Plant Science 126:145-154.

Mpelasoka BS, Behboudian MH, Mills TM (2001). Effects of deficit irrigation on fruit maturity and quality of 'Braeburn' apple. Scientia Horticulturae 90:279-290.

O’Connell MG, Goodwin I (2007). Responses of 'Pink Lady' apple to deficit irrigation and partial rootzone drying: physiology, growth, yield, and fruit quality. Australian Journal Agriculture Research 58(11):1068-1076.

Önder S, Kanber R, Önder D, Kapur B (2005). The differences
517 of possibility of global climate changing on irrigation methods and management techniques. In: GAP IV. Congress of Agriculture, 21-23 September, Şanlıurfa, Turkey:11281135.

Petillo GM, Puppo L, Morales P, Hayashi R (2009). Young apple trees response to water stress: early results. Sixth International Symposium on Irrigation of Horticultural Crops, November 2-6, 2009, Chile:273-280.

Talluto G, Farina V, Volpe G, Lo Bianco R (2008). Effects of partial rootzone drying and rootstock vigour on growth and fruit quality of 'Pink Lady' apple trees in Mediterranean environments. Australian Journal of Agricultural Research 59:785-794.

Yildırım O (2005). Irrigation Project Design. Ankara University Agriculture Faculty Publishing: 1542, Lesson book: 495, Ankara:348.

Zaliha WSW, Singh Z (2009a). Fruit quality and postharvest performance of Cripps Pink apple in relation to withholding irrigation. Proceedings of the Sixth International Postharvest Symposium, April 8-12, Antalya 1:147-154.

Zaliha WSW, Singh Z (2009b). Impact of regulated deficit irrigation on fruit quality and postharvest storage performance of 'Cripps Pink' apple. Proceedings of the Sixth International Postharvest Symposium, April 8-12, Antalya 1:155-162. 